\title{
KOMUNIKASI LINGKUNGAN DALAM MENGEMBANGKAN KELESTARIAN HUTAN
}

\author{
Ch. Herutomo ${ }^{1}$, S. Bekti Istiyanto ${ }^{2 *}$ \\ ${ }^{1,2}$ Universitas Jenderal Soedirman, Purwokerto, Indonesia \\ "bektiis@yahoo.com
}

\begin{abstract}
Forest sustainability will be maintained if there is sustainability of the ecological and economic functions of the forest, the ecological function is the fulfillment of forest resources as the carrying capacity of the environment and the economic function of the forest can improve the welfare of the community If the forest is damaged then these two functions will not be fulfilled. This is where community participation-based environmental communication is needed. The purpose of this study is to describe forest functions that require community participation which are grown through conceptual-based environmental communication. This study uses qualitative descriptive method. The result of this research is that sustainable forest development through the approach of welfare and community participation as a social forest concept can be positively correlated with the sustainability of the ecological and economic functions of forest resources, so that the community has a high sense of belonging to the forest which is positively correlated with the importance of maintaining forest sustainability. The need for forest conservation requires good environmental communication that can foster public awareness and participation in institutionally sustainable forest management such as the Community Forest Management Communication Forum (FK PHBM).
\end{abstract}

Keywords: environmental communication, participation, sustainable forest, forest village

\begin{abstract}
Abstrak
Kelestarian hutan akan terjaga apabila ada keberlanjutan fungsi ekologi dan ekonomi hutan, fungsi ekologi adalah terpenuhinya sumber daya hutan sebagai daya dukung lingkungan dan fungsi ekonomi hutan dapat meningkatkan kesejahteraan masyarakat. Bila hutan rusak maka kedua fungsi ini tidak akan terpenuhi. Disinilah dibutuhkan komunikasi lingkungan berbasis partisipasi masyarakat. Tujuan penelitian ini adalah mendeskrisikan fungsi hutan yang membutuhkan partisipasi masyarakat yang ditumbuhkan melalui komunikasi lingkungan berbasis konseptual. Penelitian ini menggunakan metode deskriptif kualitatif. Hasil penelitian ini adalah pengembangan hutan lestari melalui pendekatan kesejahteraan dan partisipasi masyarakat sebagai konsep hutan sosial dapat berkorelasi positif dengan keberlanjutan fungsi ekologi dan ekonomi sumberdaya hutan, sehingga masyarakat mempunyai sense of belonging yang tinggi terhadap hutan yang berkorelasi positif pada pentingnya menjaga kelestarian hutan. Pada kebutuhan pelestarian hutan diperlukan adanya komunikasi lingkungan yang baik yang dapat menumbuhkan kesadaran dan partisipasi masyarakat dalam pengelolaan hutan lestari secara kelembagaan seperti Forum Komunikasi Pengelolaan Hutan Bersama Masyarakat (FK PHBM).
\end{abstract}

Kata kunci: komunikasi lingkungan, partisipasi masyarakat, hutan lestari, desa hutan 


\section{PENDAHULUAN}

$\begin{array}{ccr}\text { Isu } & \text { lingkungan } & \text { menjadi } \\ \text { perbincangan } & \text { sehari-hari } & \text { yang }\end{array}$ mendominasi baik bersifat ilmiah maupun pembicaraan di media massa. Bukan hanya karena berkaitan langsung dengan kehidupan manusia, tapi lebih disebabkan semakin meningkatnya permasalahan lingkungan. Mulai bencana alam yang disebabkan faktor lingkungan akibat ulah manusia, hingga perubahan iklim yang tak terkendali.

Membahas kelestarian hutan tidak bisa dipisahkan dari keberkelanjutan sumber daya hutan yang menuntut adanya keberlanjutan fungsi ekologis dan ekonomi hutan. Fungsi ekologi hutan adalah terpenuhinya hutan sebagai daya dukung lingkungan seperti untuk resapan air, mencegah banjir, kekeringan dan tanah longsor. Sedangkan fungsi ekonomi hutan adalah melalui produk hutan seperti kayu maupun non kayu untuk meningkatkan kesejahteraan masyarakat. Keberlanjutan kedua fungsi hutan tersebut membutuhkan partisipasi masyarakat yang dapat ditumbuhkan salah satunya melalui komunikasi lingkungan Cox (2010) menjelaskan komunikasi lingkungan sebagai media pragmatis dan konstitutif untuk memberikan pemahaman kepada masyarakat mengenai lingkungan, seperti halnya hubungan antarmanusia dengan alam. Hal itu merupakan medium simbolis untuk membangun kesepahaman masyarakat terhadap permasalahan lingkungan (Fitriyarini, 2013). Komunikasi lingkungan merupakan suatu sub bidang ilmu komunikasi yang didalamnya terdapat beberapa area studi yang berbeda atau interdisipliner. Namun demikian komunikasi lingkungan pada prinsipnya memiliki dua fungsi utama yaitu: 1 . Fungsi pragmatis, yang meliputi fungsi untuk mendidik, member peringatan (alert), memobilisasi dan fungsi persuasif; 2 . Fungsi konstitusif, dimana dalam hal ini bahasa dan simbol-simbol lainnya berperan dalam membentuk persepsi kita mengenai realitas dan sifat (nature) masalah lingkungan (Cox R, 2013).

Area studi dari komunikasi lingkungan mencakup: 1. Retorika dan wacana lingkungan; merupakan area paling luas dalam studi komunikasi lingkungan yang mencakup retorika dari aktivis lingkungan, tulisan mengenai lingkungan, kampanye kehumasan bisnis serta media dan website; 2. Media dan jurnalisme lingkungan; merupakan area studi yang fokus pada bagaimana pemberitaan, iklan, program komersial dan situs internet menggambarkan masalah alam dan lingkungan. Area studi ini juga mencakup dampak dari media terhadap perilaku masyarakat hingga agenda-setting dan framing media. 3. Partisipasi publik dalam pengambilan keputusan mengenai isu lingkungan; 4. Edukasi publik dan kampanye advokasi atau disebut juga social marketing; merupakan area studi yang mencakup kampanye-kampanye yang bertujuan untuk merubah perilaku masyarakat untuk mencapai suatu tujuan sosial atau linggkungan yang diinginkan. 5. Kolaborasi lingkungan dan resolusi konflik; merupakan area studi yang mengkaji model alternatif dalam mengatasi ketidakpuasan terhadap partisipasi publik dan metode resolusi konflik. Aspek penting dalam area studi ini adalah kolaborasi dengan cara mengundang para pemangku kepentingan untuk terlibat dalam diskusi pemecahan masalah dan bukan dalam bentuk advokasi maupun debat. 6. Komunikasi risiko; area studi yang secara tradisional mengevaluasi keefektifan strategi komunikasi dalam menyampaikan informasi teknis mengenai kesehatan hingga pendekatan yang lebih modern, yaitu melihat dampak dari pemahaman masyarakat terhadap risiko terhadap penilaian publik dalam menerima risiko. 7. Reprentasi isu lingkungan dalam budaya populer dan green marketing; merupakan area studi yang mengkaji 
penggunaan gambar, musik, program televisi, fotografi dan iklan komersial dalam mempengaruhi perilaku masyarakat terhadap lingkungan (Cox R, 2013)

Komunikasi lingkungan mulai muncul di awal tahun 1960-an saat Rachel Carson mengemukakan bahaya pestisida terhadap kesehatan manusia dan dampaknya terhadap lingkungan, sehingga kemunikasi lingkungan selalu disejajarkan dan dikaitkan dengan komunikasi kesehatan (Willoughby \& Smith, 2016). Burgess \& Harrison (1998) berpendapat wacana mengenai lingkungan antara tahun 80 hingga 90an, berkembang dari yang semula tidak terlalu banyak dibahas menjadi aspek yang diperhatikan dalam hal pengukuran keberlanjutannya. Komunikasi lingkungan mencakup analisis komparatif dari proses sosial dan budaya dimana di dalamnya publik dapat memahami masalah-masalah lingkungan global, dan sejauh yang pemahaman tersebut diterjemahkan ke dalam perubahan praktek pada tingkat individu dan rumah tangga. Aspek keberlanjutan tersebut didasarkan pada keyakinan bahwa individu dan lembaga dapat dibujuk untuk menerima tanggung jawab terhadap munculnya masalah lingkungan dan mengubah praktik sehari-hari mereka demi meringankan dampak lingkungan di masa depan (Ardian, 2019)

Penelitian komunikasi lingkungan dalam tiga hingga empat dekade terakhir menunjukkan tren dan pendekatan dalam penelitian yang menyoroti peran yang dimainkan oleh media serta proses komunikasi dalam masyarakat dan kehidupan politik secara sempit dan lebih banyak membahas masalah keilmuan, kesehatan dan resiko lingkungan (Hansen A, 2011). Hansen menyoroti tentang adanya kebutuhan untuk menggunakan kembali pendekatan "tradisional" terhadap tiga fokus utama penelitian komunikasi lingkungan yang meliputi: produksi/konstruksi pesan media dan komunikasi publik; isi/pesan media komunikasi; dan dampak media dan komunikasi publik terhadap pembaca atau pemirsanya yang mencakup suara-suara yang berasal dari politikus, ilmuwan, ekspert, pemerintah dan LSM.

Setelah reformasi tahun 1998 partisipasi masyarakat dalam pengelolaan hutan khususnya hutan produksi ternyata dapat merubah sruktur dan fungsi hutan yang dikembangkan melalui konsep "social forestry" atau hutan sosial yang di Indonesia diadopsi melalui konsep Pengelolaan Hutan Berkelanjutan (PHBM) yang dilakukan oleh Perhutani. Perubahan fungsi dan struktur hutan banyak memberikan manfaat ekonomi kepada masyarakat, sehingga dapat meningkatkan kesejahteraan masyarakat desa hutan melalui sharing produk hutan baik kayu maupun non kayu yang dilakukan melalui konsep hutan sosial yang sesuai dengan pembangunan berkelanjutan.

Pembangunan berkelanjutan yang berwawasan lingkungan atau juga disebut "sustainable development" yang menggambarkan adanya saling ketergantungan antara pembangunan dan lingkungan telah setengah abad menjadi perhatian serius dari banyak negara-negara di dunia (Santoso, 2011). Pembangunan berkelanjutan dirumuskan sebagai proses pembanguan yang tidak boleh melampui daya dukung lingkungan termasuk sumber daya hutan sehingga fungsi ekologi dan ekonomi lingkungan selalu dapat terjamin, maka pengelolaan sumber daya alam harus selalu mengacu aspek pelestarian lingkungan dan konservasi, maka eksploitasi sumber alam demi kepentingan ekonomi semata akan merusak daya dukung lingkungan (Hayati, 2007)

Terjadinya penjarahan lahan hutan, pengalihan fungsi lahan hutan dan illegal loging telah memberikan kontribusi yang sangat besar terjadinya degradasi dan deforestasi hutan. Besarnya degradasi dan deforestasi hutan jelas berpengaruh besar 
terhadap kualitas dan daya dukung lingkungan sumber daya hutan (Ardian, 2019).

Data Kementerian Lingkungan Hidup dan Kehutanan (2016) hutan yang rusak dan lahan kritis yang berada di Daerah Aliran Sungai (DAS) di pulau Jawa mencapai 3,2 juta hektar dan sekitar 0,6 juta hektar berada dalam kawasan hutan negara atau $22 \%$ dari seluruh kawasan hutan negara. Secara nasional laju kerusakan hutan periode 2013 - 2016 mencapai 1,17 hektar pertahun, sebanyak $21 \%$ atau setara dengan 26 juta hektar yang telah hilang sehingga sudah tidak punya tegakan pohon lagi. Kondisi kerusakan hutan sekarang ini jelas sangat mencemaskan siapa saja.

Kerusakan hutan yang mengkhawatirkan akan merusak daya dukung hutan yang dapat menurunkan fungsi ekologi dan ekonomi hutan serta dapat menjauhkan dari konsep hutan berkelanjutan. Dengan kondisi hutan yang rusak seperti ini maka adanya tuntutan akan kebutuhan inovasi kehutanan yang disebut dengan social forestry yaitu sebuah konsep pengelolaan hutan yang berbasis komunitas atau di Indonesia dikenal dengan Pengelolaan Hutan Bersama Masyarakat (PHBM), menjadi sangatlah dibutuhkan.

Pengelolaan membutuhkan partisipasi para pemangku kepentingan. Tidak saja oleh pemerintah namun juga membutuhkan partisipasi masyarakat agar hutan lestari dapat diwujudkan. Pada titik diperlukan adanya bentuk komunikasi lingkungan yang berkelanjutan. Komponen utama dalam komunikasi lingkungan ini adalah keberadaan komunikator lingkungan yang baik. Dimana komunikator lingkungan dapat menyampaikan dan mengirimkan pesan kepada semua pihak dengan baik dan menggunakan media komunikasi yang tepat dan sesuai. Khusus dalam komunikasi lingkungan dikenal istilah konservasionis. Sesuai dalam penelitian Safina, (2008) untuk menjaga masyarakat bergerak menuju keberlanjutan, komunikator lingkungan harus bekerja dengan terampil dengan lebih dari sekadar informasi. Para konservasionis, yang bagaimanapun juga terinspirasi untuk bekerja dalam konservasi bukan hanya karena informasi yang mereka miliki tetapi karena bagaimana perasaan mereka, perlu menemukan cara yang lebih baik untuk menggabungkan informasi ilmiah dengan nilai-nilai kemanusiaan yang lebih luas.

Dalam lembaga tersebut ada fungsi komunikasi lingkungan yaitu Forum Komunikasi Pengelolaan Hutan Bersama Masyarakat (FK PHBM). Keberadaan komunikasi lingkungan untuk mengembangkan keberlanjutan sumber daya hutan tidak hanya melalui komunikasi kelembagaan, seperti Forum Komunikasi Pengelolaan Hutan Bersama Masyarakat (FK PHBM) saja akan tetapi juga bisa dengan memanfaatkan media massa. Hal ini sesuai dengan hasil Konferensi Nasional Pembangunan Berkelanjutan di Yogyakarta pada tahun 2004 yang merekomendasikan agar memanfaatkan media massa untuk mengembangkan konsep pembangunan berkelanjutan (Hardjasoemantri, 2005).

Media massa sebagai bagian dari civil society diperlukan sekali dalam upaya pengelolaan lingkungan termasuk sumber daya hutan. Undang - Undang no 40 tahun 1999 tentang pers dan Undang-Undang no 23 tahun 1997 tentang pengelolaan lingkungan hidup telah menetapkan bagaimana keterkaitan media massa dan pengelolaan lingkungan yang meliputi partisipasi masyarakat dan transparansi dalam pengelolaan lingkungan. Media massa memiliki peran signifikan dalam mensosialisasikan berbagai wawasan, termasuk wawasan tentang kelestarian lingkungan hidup. Dalam konteks ini, media mengungkap isu-isu baru yang menjadi perhatian banyak pihak, misalnya 
tentang pemanasan global dan kerusakan lingkungan yang akhir-akhir ini kian parah. Isu-isu lingkungan yang terkadang dianggap kurang populer atau kurang menjual cukup mendapat tempat di beberapa media. Dengan kata lain, media cukup memiliki kepedulian terhadap upaya pelestarian lingkungan. Namun tetap saja, porsi pemberitaan politik jelas lebih dominan jika dibanding dengan pemberitaan isu lingkungan. Pada dasarnya media massa memegang peranan sangat penting dalam membentuk sikap mental masyarakat, termasuk dalam bersikap terhadap lingkungan.

Penelitian Fitriyarini, (2013) dijelaskan pentingnya pemberitaan di media massa dalam mendeskripsikan dan mendukung upaya untuk mengkritisi pemerintah pada isu-isu lingkungan. Media massa seringkali terlambat atau lamban dalam keikut sertaan untuk mengkritisi isuisu lingkungan dan terutama persoalan kehutanan. Akibatnya seringkali isu-isu komunikasi lingkungan dan masyarakat hutan menjadi isu yang asing dan tidak semenarik isu-isu lain dalam pembangunan di Indonesia. Isu lingkungan seakan tidak dianggap penting dan masyarakat cenderung lebih cepat ketika merespon permasalahan lainnya, seperti isu-isu politik, hukum, ekonomi, dan sebagainya (Harun, 2009; Wiwoho, 2017 dalam Putri, 2017).

Dalam pandangan konstruktivisme terkait media massa, menurut Bennet, sebagaimana dikutip oleh Hidayat (1997 : 20), media massa bukan hanya sebagai saluran pesan, tetapi sebagai subyek yang mengkonstruksi realitas, pandangan, bias dan pemihakannya. Di sini media massa dipandang sebagai agen konstruksi sosial yang mendefinisikan realitas, pandangan ini menolak pendapat yang menyatakan bahwa media merupakan tempat saluran yang bebas. Begitu pula berita yang di baca dan didengar dari media massa bukan hanya menggambarkan realitas, dan menunjukkan sumber berita tetapi juga konstruksi dari media itu sendiri (Muslim, 2013)

Tidak kalah penting dalam persoalan lingkungan dan kehutanan ini adalah adanya partisipasi masyarakat. Partisipasi didefinisikan sebagai karakteristik mental/pikiran dan emosi/perasaan seseorang dalam situasi kelompok yang mendorongnya untuk memberikan sumbangan kepada kelompok dalam usaha mencapai tujuan serta turut bertanggung jawab terhadap usaha yang bersangkutan (Santosa, 1998:13 dalam Sulistiyorini et al., 2015)

Penelitian Istiyanto

disebutkan bahwa partisipasi masyarakat merupakan kunci dalam sebuah program pembangunan, baik dalam perencanaan, tahap pelaksanaan, hingga tahap evaluasinya. Bahkan disebutkan dalam penelitian Herutomo et al., (2015) partisipasi masyarakat ini merupakan kebutuhan mutlak untuk keberhasilan pembangunan itu sendiri. Rangkaian konsep partisipasi dalam sebuah program pembangunan akan lebih terasa mengikat masyarakat ketika mereka berfungsi dan berperan sebagai subyek dan bukan hanya obyek pembangunan yang lebih pasif. Dalam kasus pembangunan pasca bencana yang dilakukan oleh Herutomo et al., (2015) tersebut dijelaskan bahwa masyarakat akan merasakan program yang direncanakan bila mereka dilibatkan sedari awal sebagai bagian aktif. Mereka akan ikut menjaga dan melestarikan kebijakan dan implementasinya karena akan berhubungan dengan kebutuhan mereka sendiri. Partisipasi sejak awal sebuah program pembangunan dari dan untuk masyarakat inilah yang menjadi dasar dan kunci keberhasilan program pembangunan yang dicanangkan. Tanggung jawab perlindungan dan pengelolaan lingkungan hidup dewasa ini bukan semata-mata menjadi tanggung jawab pemerintah atau negara saja. Pelibatan atau partisipasi 
masyarakat mutlak diperlukan dalam menjaga dan mengawasi lingkungan hidup agar dapat lebih baik dan lebih sehat (Susila Wibawa, 2019).

Dalam penelitian ini berbeda dengan penelitian-penelitian sebelumnya terutama pada pendekatan jenis konsep komunikasi lingkungan yang dianalisis, selain metode penelitian yang dipilih. Penguatan komunikasi lingkungan dalam pelestarian hutam dilihat dalam kemanfaatan hutan. Kelestarian hutan akan dianggap dalam kondisi yang baik bila ada keberlanjutan fungsi ekologi dan fungsi ekonomi dari hutan itu sendiri. Makna dari fungsi ekologi hutan adalah terpenuhinya sumber daya hutan sebagai daya dukung lingkungan. Dan fungsi ekonomi hutan ditujukan untuk dapat meningkatkan kesejahteraan masyarakat pengguna hutan atau masyarakat desa hutan yang hidup bergantung dengan hutan dan tidak bisa dipisahkan dari sumber daya hutan. Bila kelestarian hutan rusak atau tidak terjaga, maka kedua fungsi ini tidak akan terpenuhi. Di sinilah dibutuhkan komunikasi lingkungan yang tepat dan sesuai. Kajian konseptual tentang komunikasi lingkungan ini akan berbasis kepada pelibatan atau partisipasi masyarakat.

Tujuan penelitian ini adalah mendeskrisikan fungsi hutan yang membutuhkan partisipasi masyarakat yang ditumbuhkan melalui komunikasi lingkungan berbasis konseptual, sehingga akan sesuai bila menggunakan metode penelitian studi literatur yang akan mengkaji dan menganalisis permasalahan penelitian tentang komunikasi lingkungan dalam kaitannya dengan pelestarian hutan menggunakan banyak referensi yang terkait. Penelitian ini sangat urgen dilakukan dikarenakan penelitian tentang masyarakat hutan lebih banyak dilakukan terkait dengan konflik sosial atau persoalan masyarakat yang dibenturkan dengan fungsi ekonomi hutan. Menjadikan komunikasi lingkungan yang setara dengan pentingnya pelibatan partisipasi masyarakat menjadi sesuatu yang baru dan perlu dikembangkan dalam penelitianpenelitian ilmiah.

Penelitian yang akan lengkap membahas fungsi ekologi hutan yang seimbang dengan fungsi ekonomi hutan sangatlah perlu dilakukan. Dan itu dapat terjadi manakala masyarakat dilihatkan. Dalam beberapa konsep pelibatan masyarakat ini membutuhkan peranan komunikasi yang sesuai seperti komunikasi lingkungan.

\section{METODOLOGI}

Dalam penelitian ini berparadigma konstruktivis dimana suatu kebenaran atas realitas sosial dilihat sebagai hasil konstruksi sosial (Hanitzsch, 2001). Karenanya, kebenaran realitas sosial dianggap bersifat relative dan bukan sesuatu yang mutlak atau pasti.

Sementara untuk metode penelitian ini menggunakan studi literatur. Menurut Rahayu Rian Sri, (2018) studi literatur merupakan yang mengumpulkan beberapa penelitian terdahulu untuk menjawab permasalahan yang diteliti yaitu komunikasi lingkungan kehutanan. Kegiatan pengumpulan data merupakan rangkaian kegiatan yang berkenaan dengan aktivitas mengumpulkan data pustaka, membaca dan mencatat, serta mengelolah bahan penelitian. Studi literatur ini menggunakan pencarian data terhadap berbagai sumber tertulis, baik berupa buku-buku, arsip, majalah, artikel, dan jurnal penelitian, atau dokumen-dokumen yang relevan dengan permasalahan yang dikaji.

Studi literatur dalam penelitian ini berusaha mendeskripsikan apa yang menjadi tujuan penulisan dengan melakukan analisis bersumber dari kajian literatur-literatur yang berkaitan dengan tema komunikasi lingkungan, kehutanan, produk Undang-Undang 
kehutanan/lingkungan dan data sekunder yang berkaitan tentang masyarakat hutan. Dengan studi literatur ini memungkinkan peneliti dapat menganalisis, mengkaji dan mendalami pokok permasalahan secara komprehensif dan dapat mengambil kesimpulan yang obyektif dan akurat untuk mencari akar permasalahan dan solusi atas permasalahan yang diteliti.

\section{HASIL DAN PEMBAHASAN}

Komunikasi lingkungan menurut Cox, (2010) merupakan media pragmatis dan konstitutif untuk memberikan pemahaman kepada masyarakat mengenai lingkungan. Komunikator utama dalam komunikasi lingkungan adalah pemerintah dan organisasi non pemerintah yang punya komitmen terhadap pengelolaan lingkungan. Pola komunikasi lingkungan untuk menumbuhkan kesadaran dan partisipasi masyarakat dalam mengelola sumber daya hutan bersifat dialogis yang lebih banyak terjadi pada komunikasi kelompok. Wiryono (1998) menjelaskan keberadaan pola komunikasi dibentuk untuk mengidentikasi dan mengkategorikan unsur-unsur yang relevan dari suatu proses komunikasi khususnya komunikasi antarpribadi. Efektivitasnya tergantung bagaimana relevansi antara pola komunikasi yang dipakai dengan kondisi sosial, budaya dan psikologis khalayak.

Komunikasi yang efektif menurut Susanto, (1989) dapat diketahui dari persentase antara khalayak yang dapat dipengaruhi dengan yang tidak. Di samping itu efektivitas komunikasi juga dapat diketahui dari efeknya pada khalayak yaitu kognitif, afektif, dan konatif. Komunikasi yang efektif jika terjadi dalam suasana yang menguntungkan, menggunakan bahasa yang mudah dimengerti dan pesannya menggugah perhatian dan minat komunikan sebagai partner komunikasi (Istiyanto, 2015). Termasuk dalam persoalan komunikasi antara manusia dengan lingkungan dimana mereka tinggal. Secara sederhana konsep tersebut disederhanakan dengan istilah komunikasi lingkungan.

Komunikasi lingkungan dan kebijakan lingkungan terdapat hubungan yang saling mempengaruhi karena komunikasi lingkungan tidak hanya menginformasikan secara linier atau botton up mengenai masalah lingkungan tetapi lebih pada sharing informasi lingkungan secara dialogis kepada semua pemangku kepentingan atas sebuah lingkungan tertentu (Wahyudin, 2017). Di samping itu fungsi komunikasi lingkungan menyampaikan tuntutan (policy demand) masyarakat dalam pengelolaan lingkungan termasuk masalah lingkungan hutan.

Salah satu bentuk lembaga masyarakat yang menjadi sarana berkomunikasi adalah Forum Komunikasi Pengelolaan Hutan Bersama Masyarakat atau disingkat dengan FK PHBM. FK PHBM ini merupakan forum komunikasi yang selalu melakukan proses komunikasi lingkungan untuk mengembangkan kelestarian hutan. Lembaga ini merupakan sarana kolaboratif yang berbasis pada masyarakat desa hutan dengan melibatkan Perum Perhutani, Lembaga Masyarakat Desa Hutan (LMDH), pemangku kepentingan (stakeholders) hutan, dan pemerintahan setempat.

efektif $\begin{array}{ccc}\text { Komunikasi lingkungan yang } \\ \text { diharuskan agar dapat }\end{array}$
menumbuhkan harapan atau keinginan masyarakat yang berorientasi lebih pada masa mendatang. Maka dalam Forum Komunikasi PHBM inilah harapan dan keinginan tersebut diwujudkan dalam hutan yang lestari. Hutan yang lestari atau berkelanjutan tersebut dapat terwujud bila masyarakat desa hutan dapat tumbuh kesadaran akan pentingnya kelestarian hutan dengan menjaga hutan tidak merusak atau merambah hutan tanpa memikirkan akan dampak negatifnya, sehingga fungsi ekologi dan fungsi ekonomi hutan bagi 
masyarakat desa hutan akan terus terjaga dan berkelanjutan.

Forum Komunikasi lingkungan yang terjadi dalam rembug desa di masyarakat desa hutan ini dilaksanakan secara berkala periode waktunya. Dalam forum ini mereka akan saling menyampaikan informasi yang berupa informational message seperti pemberitahuan tentang masalah hutan, instruksional message seperti perintah untuk menanam tanaman di bawah tegakan dengan sistem tumpang sari, dan motivational message seperti meningkatkan kesadaran akan pentingnya menjaga kelestarian hutan (Damanik, 2019).

Dalam banyak kasus kehutanan seperti yang diuraikan dalam penelitian Cox, (2010) data bahwa masyarakat desa hutan ternyata rata-rata berpendidikan rendah, maka informasi yang disampaikan dalam forum komunikasi agar mudah dimengerti maka menggunakan "rekayasa pemahaman" sesuai kapasitas pengethuan dan pemahaman masyarakat desa hutan sendiri yaitu menggunakan: lambang, interpretasi cara lain untuk menyampaikan pesan; rujukan, menunjukkan obyek, peristiwa, benda; dan Interpretasi, ukiran untuk melihat lambang atau hal yang diwakili lambang dengan lebih sederhana agar mudah dipahami. Sementara untuk komunikasi lingkungan dalam forum rembug desa terjadi dalam bentuk perilaku spontan, terjadi secara tiba-tiba, serta merta tanpa berpikir mendalam dulu yang sering menimbulkan gelak tawa, perilaku scripted karena dorongan faktor kebiasaan seperti nampak dalam logat atau dialek, dan perilaku contrived, yang dipengaruhi motif kognitif dan sikap rasionalitasnya seperti yang penting tidak tidak asal bunyi (Istiyanto, 2017)

Dalam forum komunikasi masyarakat desa hutan ini mereka akan berbagi banyak hal seperti pikiran yang mereka alami, perasaan empati yang besar karena mereka merasa saling tergantung (Istiyanto, 2017). Mereka membuat aturan yang mengikat masyarakat desa hutan dan aturan itu mempengaruhi sikap konformitas di antara masyarakat desa hutan seperti ketika menanam tanaman yang sama di bawah tegakan, dengan harapan tidak terjadi konflik dan perbedaan yang besar di antara mereka sendiri.

Komunikasi lingkungan dalam forum komunikasi PHBM dapat memberi keuntungan antara lain: sebagai wadah pertukaran informasi di antara stakeholder, Perum Perhutani dan Lembaga Masyarakat Desa Hutan (LMDH). Selain itu, untuk mengambil keputusan efektif yang fokusnya pada masalah bersama dan mengendalikan kebijakan melalui koordinasi lintas sektoral, serta mengembangkan kapasitas kelembagaan Perhutani, LMDH, stakeholder dan pemerintah setempat (Hardjasoemantri, 2005)

Komunikasi lingkungan ini senyatanya tidak hanya terjadi dalam konteks kelembagaan saja, tetapi juga dapat dilakukan melalui media massa sebagai salah satu ciri masyarakat sipil (civil society). Penggunaan media massa ini dilakukan melalui isi pemberitaannya yang dapat menumbuhkan kesadaran masyarakat yang lebih luas akan pentingnya kelestarian hutan (Yenrizal, 2016). Berkenaaan dengan itu maka konferensi nasional tentang Pembangunan Berkelanjutan pada Tahun 2004 di Yogyakarta merekomendasikan komunikasi dan informasi dimasukkan dalam konsep Pembangunan Berkelanjutan. Maka implikasi dari rekomendasi itu adalah media massa dianggap mempunyai peranan yang cukup besar dalam menambah pengetahuan dan menumbuhkan kesadaran masyarakat terutama masyarakat desa hutan tentang pentingnya pengelolaan lingkungan 
termasuk hutan oleh tangan mereka sendiri.

Menurut penelitian terdahulu dari Ader (dalam Atmakusumah, 1996)) yang mengkaitkan berita lingkungan di media massa dengan pendapat khalayak, menyimpulkan media massa dapat melakukan pencerahan masalah lingkungan terhadap masyarakat. Hutan sebagai salah satu modal pembanguan nasional mempunyai manfaat yang nyata bagi kehidupan rakyat Indonesia baik manfaat ekonomi, ekologi dan sosial budaya. Oleh karena itu, sumber daya hutan harus dikelola dan dimanfaatkan secara berkesinambungan baik untuk generasi sekarang maupun yang akan datang.

Dalam Undang-Undang Nomor 41 tahun 1999 tentang Kehutanan ditetapkan bahwa hutan sebagai salah satu penyangga kehidupan dan sumber kemakmuran rakyat. Maka hutan harus dijaga daya dukungnya secara keberlanjutan, diurus dengan akhlak mulia, asas kerakyatan, asas keadilan, asas kebersamaan, asas keterbukaan, asas keterbukaan dan asas keterpaduan.

Status dan fungsi hutan diatur dalam pasal 5 sampai dengan 9 Undang Kehutanan Nomor 41 tahun 1999. Tentang status hutan yang diatur dalam pasal 5, bahwa status hutan terdiri hutan negara dan hutan hak, sedang fungsi hutan diatur dalam pasal 6 ayat 1 yang menyatakan hutan mempunyai fungsi konservasi, fungsi lindung dan fungsi produksi (Undang-Undang No 41 tahun 1999, Tentang Kehutanan,). Selain pembagian hutan berdasarkan fungsinya, pemerintah dapat menetapkan kawasan hutan tertentu untuk tujuan khusus untuk kepentingan umum seperti untuk pendidikan, penelitan, latihan dan penetapan untuk tujuan khusus ini tidak boleh mengubah fungsi pokok hutan. Tujuan utama dari aktivitas ini adalah tercapainya hutan lestari bagi semua pemangku kepentingan hutan.
Pengelolaan Hutan Lestari atau Sustainable Forest Management menuntut Perum Perhutani sebagai penyelenggara kegiatan pengelolaan sumberdaya hutan untuk mencapai satu atau lebih tujuan yang telah ditetapkan. Semua berkaitan dengan produksi kayu dan non kayu dengan mengoptimalkan peran dan fungsi hutan secara lestari ekonomi, lestari lingkungan, lestari sosial kemasyarakatan.

Pengelolaan hutan lestari (Perhutani, 2002) pada dasarnya meliputi tiga aspek yaitu: ekonomi (produksi), sosial budaya dan lingkungan secara proporsional. Pelaksanaannya mengacu pada prinsip-prinsip pengelolaan hutan yang diakui secara internasional. Pengakuan atas pemenuhan prinsip-prinsip tersebut diwujudkan dalam sertifikat yang diterbitkan oleh lembaga sertifikasi internasional independen yaitu Forest Stewardship Council (FSC), berupa ekolabel yang dilekatkan pada produk hutan yang menandakan bahwa perusahaan telah memenuhi prinsip, kriteria pengelolaan hutan lestari atau berkelanjutan.

$\begin{array}{lr}\text { Secara empiris } & \text { pengembangan } \\ \text { hutan lestari atau } & \text { berkelanjutan } \\ \text { berkelanjutan menurut } & \text { Perhutani }\end{array}$ (2002) didasari karakteristik permasalahan hutan yang dihadapi dan pengalaman panjang dalam mengelola hutan yaitu: pertama, Community Based Forest Managemen (CBFM), pengelolaan hutan melibatkan masyarakat sekitar hutan untuk berpartisipasi akatif mulai dari perencanaan, pengelolaan hingga pengawasan hutan dimana ketiga prinsip tersebut oleh Perum Perhutani dijabarkan dalam program PHBM. Kedua, adanya Resources Based Forest Management, usaha Perum Perhutani tidak semata-mata memproduksi kayu dan hasil hutan lainnya tetapi juga mengelola ekosistem dan seluruh sumber daya hutan yang terkandung di dalam maupun di permukaan seperti air, galian $\mathrm{C}$, agrobisnis 
yang ditujukan bagi kesejahteraan masyarakat. Ketiga, yaitu penerapan Good Corporate Gavermance dalam seluruh aspek pengelolaan hutan, artinya bahwa seluruh aktivitas pengelolaan hutan harus memenuhi unsur asas transparansi, fairness, akuntabilitas, kemandirian, kewajaran serta bebas KKN (korupsi, kolusi, nepotisme) untuk perbaikan manajemen yang dapat menjamin keberlanjutan hutan.

Membahas hutan lestari atau berkelanjutan secara akademik tidak bisa dipisahkan dari konsep pembangunan berkelanjutan yang menurut penelitian Soerjani (1997) menyebutkan pembangunan berkelanjutan berupa terpeliharanya "total natural stock" pada tingkat yang sama atau lebih tinggi dibandingkan dengan keadaan sekarang. Konsep kelestarian hutan yang dilakukan oleh negara mempunyai dimensi yang lebih luas yaitu memenuhi aspek ekologi, sosial ekonomi, teritorial bagi masyarakat, orientasi yang hanya semata mengutamakan produk hutan secara periodik sudah ditinggalkan. Di sinilah menjadi sangat penting tentang peranan media massa dan partisipasi masyarakat.

$$
\text { Dalam konteks komunikasi }
$$

lingkungan, media massa sebenarnya menjadi dan memegang peranan penting dalam meningkatkan taraf pengetahuan dan pemahaman masyarakat untuk selalu mau terlibat dalam menjaga dan mewujudkan hutan lestari. Media massa seperti yang disebutkan oleh Atmakusumah, (1996) semestinya menjadi media penyampai pesan tentang lingkungan juga. Media massa dalam isian pemberitaan perlu mengadendakan focus pembahasan atas tema-tema lingkungan sehingga akan memberikan dampak perubahan tingkat kognisi masyarakat.

Dengan data status sosial masyarakat desa hutan yang mayoritas berada dalam level pendidikan yang tidak terlalu tinggi dan di sisi lain akan kebutuhan informasi yang demikian cepat, terutama di masa perkembangan informasi yang sangat massif dikarenakan teknologi internet yang dibutuhkan semua orang, peranan media masa dapat menjadi satu bagian yang sentral sebagai sumber informasi yang terpercaya oleh masyarakat. Di sinilah yang dapat menjadi dasar perubahan pengetahuan dan sikap masyarakat desa hutan dalam memandang hutan sebagai sebuah kebutuhan sumber daya yang vital. Dengan berbagai informasi yang dipercaya maka isu-isu pelestarian hutan akan menjadi tema sentral bagi masyarakat. Hal ini sesuai dengan hasil penelitian dari Fitryarini (2013) yang mengungkapkan pengaruh pemberitaan di media massa dalam perubahan cara pandang dan sikap masyarakat di Provinsi Kalimantan Timur atas kasus-kasus hutan yang marak terjadi. Dampak positif yang terjadi adalah masyarakat desa hutan semakin menyadari kebutuhan atas kelestarian hutan di sekitar mereka.

Bentuk berikut dalam komunikasi lingkungan yang spesifik adalah perlunya melibatkan partisipasi masyarakat dalam ikut menjaga pelestarian hutan. Istilah hutan lestari dapat dilihat dalam dua kondisi kemanfaatannya bagi masyarakat yaitu manfaat ekologi hutan adalah terpenuhinya sumber daya hutan sebagai daya dukung lingkungan. Yang kedua adalah fungsi ekonomi hutan yang ditujukan untuk dapat meningkatkan kesejahteraan masyarakat pengguna hutan atau masyarakat desa hutan yang hidup dari sumber daya hutan (Damanik, 2019).

Pelestarian fungsi sebuah lingkungan menggunakan komunikasi lingkungan telah dilakukan dalam penelitian Chandrabuwono dan Atika (2019) yang berlokasi di masyarakat Sungai Tabuk. Hasil penelitian tersebut menjelaskan perubahan masyarakat Sungai Tabuk dikarenakan pendekatan komunikasi lingkungan yang sesuai. Hal 
ini dapat dijadikan rujukan dalam kasus penciptaan hutan lestari bagi masyarakat desa hutan agar kedua fungsi utama hutan lestari dapat terjadi. Proses yang sama dalam melakukan keberhasilan komunikasi lingkungan adalah dengan mengoptimalkan partisipasi masyarakat.

Partisipasi masyarakat dalam aktivitas komunikasi lingkungan masyarakat desa hutan adalah dilakukan secara kelembagaan melalui Forum Komunikasi Pengeloaan Hutan Bersama Masyarakat (FK PHBM). Pilihan komunikasi kelembagaan menurut Herutomo et al., (2015) selain dilakukan komunikasi antar anggota forum komunkasi secara personal tentu sajaadalah pilihan yang lebih sesuai dengan situasi dan kondisi masyarakat desa hutan. Komunikasi lingkungan yang berbasis kelembagaan secara formal yang melibatkan partisipasi masyarakat ini akan menjadi forum kolaboratif yang berfungsi sebagai sarana koordinasi dan sinkronisasi antar pemangku kepentingan seperti pemerintah, Perum Perhutani dan masyarakat, yang diharapkan dapat berjalan dengan baik dan efektif untuk menjaga hutan itu sendiri sesuai tujuan pemanfaatan dan fungsional hutan lestari bagi semua.

\section{SIMPULAN}

Berdasarkan pada analisis pembahasan maka dapat ditarik kesimpulan bahwa pengembangan hutan lestari melalui pendekatan kesejahteraan dan partisipasi masyarakat sebagai konsep hutan sosial dapat berkorelasi positif dengan keberlanjutan fungsi ekologi dan ekonomi sumberdaya hutan, sehingga masyarakat mempunyai sense of belonging yang tinggi terhadap hutan yang berkorelasi positif pada pola pikir masyarakat desa hutan yang makin menyadari pentingnya menjaga kelestarian hutan. Pada kebutuhan pelestarian hutan diperlukan adanya komunikasi lingkungan yang baik yang dapat menumbuhkan kesadaran dan partisipasi masyarakat dalam pengelolaan hutan lestari secara kelembagaan seperti Forum Komunikasi Pengeloaan Hutan Bersama Masyarakat (FK PHBM). Adanya kelembagaan masyarakat berbasis partisipasi ini akan menjadi forum kolaboratif yang berfungsi sebagai sarana koordinasi dan sinkronisasi antar instansi terkait untuk mengembangkan hutan yang lestari yang berbasis pada masyarakat di sekitar hutan atau yang disebut sebagai desa hutan.

\section{DAFTAR PUSTAKA}

Ardian, H. Y. (2019). Kajian Teori Komunikasi Lingkungan Dalam Penelitian Pengelolaan Sumber Daya Alam. Jurnal PERSPEKTIF Komunikasi Program Studi Ilmu Komunikasi Dan Magister Ilmu Komunikasi Fakultas Ilmu Sosial Dan Ilmu Politik Universitas Muhammadiyah Jakarta. https://jurnal.umj.ac.id/index.php/pers pektif/article/download/3894/2891

Atmakusumah. (1996). Mengangkat Lingkungan Ke Media Massa. Lembaga Pers Dr. Soetomo dan Yayasan Obor Indonesia.

Cox, R. (2010). Environmental Communication and Public Sphere. SAGE Publications, Inc.

Cox R. (2013). Environmental Communication and the Public Sphere (3rd Editio). SAGE Publications, Inc.

Damanik, S. E. (2019). Pemberdayaan Masyarakat Desa Sekitar Kawasan Hutan. Uwais Inspirasi Indonesia.

Fitriyarini, I. (2013). Pemberitaan dan Persepsi Masyarakat Tentang Lingkungan Hidup di Media Cetak Lokal Provinsi Kaltim. Jurnal Ilmu Komunikasi UPNYK, 11(1), 19-29.

Hanitzsch, T. (2001). Teori Sistem Sosial dan Paradigma Konstruktivisme: Tantangan Keilmuan Jurnalistik di 
Era Informasi. Jurnal Mediator, 2(2).

Hansen A. (2011). Communication, media and environment: toward reconnecting, content and social implications of environmental communication. The International Communication Gazette, 73(1-2). https://doi.org/10.1177/17480485103 86739

Hardjasoemantri, K. (2005). Hukum Tata Lingkungan. Gadjahmada University Press.

Hayati, S. (2007). Pendidikan Lingkungan Hidup Pada Jenjang Pendidikan Dasar. Jurnal Geografi, 7(1). https://ejournal.upi.edu/index.php/gea /article/view/1712

Herutomo, C., Istiyanto, S. B., \& Unsoed, J. (2015). Program Pemulihan Ekonomi Masyarakat Pasca Bencana Erupsi Gunung Merapi di Kabupaten Klaten Jawa Tengah. Academia.Edu, $1-9$.

http://www.academia.edu/download/5 1391702/Program_Pemulihan_Ekono mi_Masyarakat.pdf

Istiyanto, S. B. (2015). Komunikasi Antar Pribadi. Literasi Bangsa.

Istiyanto, S. B. (2017). Komunikasi Pemberdayaan Masyarakat. Pustaka Ilmu.

Muslim. (2013). Konstruksi Media Tentang Serangan Israel Terhadap Lebanon. Jurnal Studi Komunikasi Dan Media, 17(1), 75-92. https://jurnal.kominfo.go.id/index.php /jskm/article/download/170104/117

Putri, M. I. (2017). Jurnalisme Lingkungan Pada Media Online Arus Utama dan Jurnalisme Warga di Era Digital: Framing Pemberitaan Banjir di Indonesia Pada. The 4th Indonesia Media Research Awards \& Summit (IMRAS) 2017, 656-678.

Rahayu Rian Sri. (2018). Studi Literatur: Peranan Bahasa Inggris Untuk Tujuan Bisnis Dan Pemasaran. Jurnal Pemasaran Kompetitif, 1(4). http://openjournal.unpam.ac.id/index. $\mathrm{php} / \mathrm{JPK} /$ article/view/1553

Safina. (2008). A Passion for This Earth: Writers, Scientists, and Activists Explore Our Relationship with Nature and the Environment (David Suzuki Foundation Series: Paperback - April 28, 2008).

Santoso, B. (2011). Pendekatan Hukum terhadap Pembangunan Berkelanjutan Melalui Pengaturan Tanggung Jawab Sosial Perusahaan. Jurnal Mimbar Hukum, November. https://doi.org/https://doi.org/10.2214 6/jmh.16163

Sulistiyorini, N. R., Darwis, R. S., \& Gutama, A. S. (2015). Partisipasi Masyarakat Dalam Pengelolaan Sampah Di Lingkungan Margaluyu Kelurahan Cicurug. Share: Social Work Journal, 5(1). https://doi.org/10.24198/share.v5i1.13 120

Susanto, A. (1989). Komunikasi Kontemporer. Binacipta.

Susila Wibawa, K. C. (2019). Mengembangkan Partisipasi Masyarakat Dalam Perlindungan dan Pengelolaan Lingkungan Hidup Untuk Pembangunan Berkelanjutan. Administrative Law and Governance Journal, 2(1), 79-92. https://doi.org/10.14710/alj.v2i1.7992

Undang-Undang No 41 tahun 1999, Tentang Kehutanan

Undang-Undang No 23 tahun 1997, Tentang Pengelolaan Lingkungan Hidup.

Undang-Undang No 41 tahun 1999, Tentang Kehutanan.

Undang-Undang No 32 tahun 2004, Tentang Otonomi Daerah

Wahyudin, U. (2017). Strategi Komunikasi Lingkungan Dalam Membangun Kepedulian Masyarakat Terhadap Lingkungan. Jurnal Common, 1(2). https://ojs.unikom.ac.id/index.php/co 
mmon/article/view/576

Willoughby JF, S. H. (2016). Communication strategies and new media platforms: exploring the synergistic potential of healthand environmental communication. Science Communication, 38(4), 535545. https://doi.org/10.1177/10755470166 48151

Yenrizal. (2016). Sungai Dalam Pemaknaan Masyarakat Pedesaan Studi Etnoekologi Komunikasi Pada Masyarakat Desa Karang Anyar, Banyuasin, Sumatera. Jurnal Nizham, 05(02 Juli-Desember 2016). 